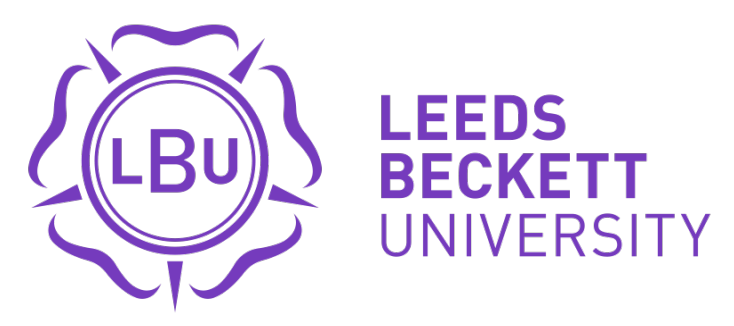

Citation:

Leese, M (2016) The bumpy road to 'becoming': Capturing the stories that teenage mothers told about their journey into motherhood. Child and Family Social Work, 21 (4). pp. 521-529. ISSN 1356-7500 DOI: https://doi.org/10.1111/cfs.12169

Link to Leeds Beckett Repository record:

https://eprints.leedsbeckett.ac.uk/id/eprint/87/

Document Version:

Article (Accepted Version)

The aim of the Leeds Beckett Repository is to provide open access to our research, as required by funder policies and permitted by publishers and copyright law.

The Leeds Beckett repository holds a wide range of publications, each of which has been checked for copyright and the relevant embargo period has been applied by the Research Services team.

We operate on a standard take-down policy. If you are the author or publisher of an output and you would like it removed from the repository, please contact us and we will investigate on a case-by-case basis.

Each thesis in the repository has been cleared where necessary by the author for third party copyright. If you would like a thesis to be removed from the repository or believe there is an issue with copyright, please contact us on openaccess@leedsbeckett.ac.uk and we will investigate on a case-by-case basis. 


\title{
The bumpy road to 'becoming': Capturing the stories that teenage mothers told about their journey into motherhood.
}

\author{
Dr Maggie Leese \\ Principal Lecturer \\ School of Social, Psychological \& Communication Sciences. \\ LEEDS METROPOLITAN UNIVERSITY \\ Calverley Building (Room CL916) \\ City Campus \\ Portland Way \\ LEEDS \\ LS1 3HE \\ Email: m.leese@leedsmet.ac.uk \\ Phone: +44 (0)113 8125613
}

\begin{abstract}
Understanding the experience of women who become mothers during their teenage years is central to ensuring that the support that is offered is appropriate to meet their needs. This paper reports on a small part of a larger ethnographic study that captured the lived experience of young mothers who were between the ages of 16-19 years that potentially typifies and illuminates the experiences of young women who become mothers in their teenage years. By collecting data from narrative interviews as well as participant and non-participant observations over an extended period of time it was possible to identify how the young women experienced a range of difficulties as they made their transition into motherhood. Drawing on the findings, this paper argues that this transition for teenage mothers can be significantly different to the experience of older mothers, and it identifies the importance of appropriate support to mediate the challenges that they face. Understanding the young women's journey to 'becoming' is critical when planning services because if their experience of support is negative, it can lead to increased levels of maternal stress and reluctance to engage with support services.
\end{abstract}

Keywords: Mothering, Family Support, Child in Need Services, Children’s Centres

\section{Introduction}

A woman's transition into motherhood is of central importance in her life and the point when she 'becomes' a mother is significant because her identity changes and she starts to understand what it actually means to be a woman (Oakley 1979, 2005). Although it is 
acknowledged that the transition into motherhood can be difficult for women of any age, this paper argues that teenage mothers face specific challenges linked to the way they are constructed negatively, both within social policy and the wider media. In addition, as Rutman et al. (2002) argued, the professionals that young mothers engage with, frequently reflect "prevailing middle-class values" (p.149), meaning that teenage motherhood is often constructed as a social problem (Macvarish, 2010). This negative portrayal can make it difficult for young mothers to resist negative labelling (Walkerdine et al. 2001) so they can be increasingly stigmatised and viewed as being 'problematic' (Wilson \& Huntington 2005; Macvarish 2010). The teenage mothers in Gregson's (2009) study were aware that they were constructed in the media as “...bad, irresponsible mothers” (p.137) and this impacted on their experience of motherhood because they were attempting to resist the 'stigma' that was applied to them.

These factors all influence the normative construction of teenage motherhood, leading to young mothers being stigmatised and viewed as 'deviant' or 'dependent' (Wilson \& Huntington 2005). The experience of teenage motherhood is complex because social class is also closely aligned with constructions of the 'good' and 'bad' mother (Allen \& Osgood, 2009). In their paper Allen \& Taylor (2012) argued that issues of class impact on the opportunities for working-class mothers to “'fit' into contemporary economic and social formation” (p.18) because they are viewed as being "excessive, destructive and out of place” (p.18). When working-class women become lone mothers at a young age they often experience poverty and social exclusion, making their transition into motherhood even more problematic (Rowlingson \& McKay, 2005). The increased focus on teenage parenting has led to increased intervention in teenage mothers' lives, leaving them open to criticisms if they refuse to engage with the support that is offered (Arai, 2009; Read et al. 2012).

\section{The study}

The data reported in this paper is taken from a larger ethnographic study that explored the experience of young mothers between the ages of 16-19 years who had all given birth during their teenage years. Although participants' backgrounds varied, most had never been employed prior to having their baby and apart from one, they all described themselves as 'working-class'. Their stories were complex and multi-faceted; some had been involved in criminal behaviour while others had a partner that was, or had been, in prison. In addition, they faced other challenges including drug and alcohol addictions, long-standing mental 
health issues, and one mother had experienced the removal of an older child from her care because of concerns about neglect. Therefore because of the nature and sensitivity of the data and the desire to maintain their anonymity it is not possible to give specifics about each individual young woman’s 'story’.

All the participants $(\mathrm{n}=12)$ were attending a support group for young parents in a Sure Start Children's Centre in the Midlands. A range of data collection methods were utilised in the larger study but this paper draws on the narrative interviews and participant and nonparticipant observations that were collected over a year. The methods were designed to capture the young mothers' journeys in order to understand the reality of their individual and collective experiences within the cultural context of the support group (Flick, 2009). It was possible for the researcher to build rapport with the young mother's because she had shared similar experiences as a young working-class teenage mother and was able to empathise with the challenges that they faced.

The data collection started with narrative interviews in a quiet room away from the other mothers, where the young women were asked to tell their 'story' about becoming a mother. This was the first stage of building a picture of their lived experiences, and by reading the narratives and listening to the audio recordings enabled an exploration of the meanings embedded within them (Bleakley, 2005). During this initial stage it was possible to identify themes that would be explored further in discussions with the mothers during the participant and non-participant observations (Blaufuss, 2007; Crang \& Cook, 2007). In this sense the initial narrative interview represented the beginning of them constructing their 'stories' because it offered a 'space' for participants to share their experiences and attempt to resolve any issues that arose for them (Taylor, 2003). Translating the stories into research data was a challenge and it was important to remember that the oral aspect of the story formed only part of the picture (Feldman et al. 2004) therefore it was crucial to note how the women told their story, how they chose to present a view of themselves, and where they positioned their own experience in relation to others (Burck, 2005; Blaufuss, 2007).

The second stage of data collection involved non-participant observation of the young women's day-to-day activities within the centre. Although initially the data collection involved non-participant observations, it soon changed to participant observation as the mothers accepted the researcher within their group (Crang \& Cook 2007). This stage lasted for nine months and detailed field notes were taken to capture how the mothers extended and 
adapted their initial narratives, dependent on the audience. During this stage there were frequent informal discussions with the young mothers both individually and in small groups where they talked about their struggles to accept their new identity as a mother. At the end of the data collection the narratives were shared individually with the young mothers and they had the opportunity to make any changes that they wanted (two of them did request slight changes to the dates of significant events).

The analysis of the second stage of the study used what Gomm (2008) referred to as thematic analysis, in which data was coded into broad themes and notes were taken to explain how each theme was defined. This initial analysis informed further data collection because it generated more questions about the barriers they faced. Data was subjected to the three stages of analysis (Creswell 2007), where there was a shift from describing what is happening to analysing the data and finally the task of interpretation. Issues of reliability and validity were considered and theoretical triangulation was used in an attempt to validate the data by considering how it related to other studies in this area (Crang \& Cook, 2007).

From this analysis it was possible to identify how the cultural/normative narratives of motherhood had impacted on the young mothers' individual experience of 'becoming'. The degree to which this transition was positive or negative was compounded by other factors including their relationships, finances, housing and the availability of informal support. By collecting data over a year it was possible to identify what influenced the young mothers' attempt to develop a sense of who they are, and perhaps more importantly, who they wanted to be. Drawing on Goffman’s (1959) ‘dramaturgical’ metaphor and Mead’s (1967) discussion of the 'self', it was possible to identify the methods used by the mothers to project positive images about teenage motherhood despite the challenges that they faced.

Utilising the concept of 'reference groups' (Shibutani 1955, 1962; Urry, 1973) it was possible to build a picture of how the mothers looked to others (family, friends, workers) to inform their interactions as they moved from one status to another in what Glaser \& Strauss (1971) described as 'status passage'. By exploring the factors that influenced their 'identity transformation' (Strauss, 1962), it was possible to understand their experience of 'becoming' in their journey towards full acceptance. 


\section{“Once I decided to keep the baby, everything changed”: Taking the first step} on the road to 'becoming'

The experience of finding out that they were pregnant took many forms along a continuum, with stories ranging from total surprise to planned pregnancies. The levels of support available to the young women was also varied and ranged from very supportive relationships with family and friends, to total isolation. The young mothers all recalled a feeling of responsibility when they realised that they needed to put their child's needs before their own and for Joanne this happened when she decided to keep her baby.

\footnotetext{
Joanne: I knew that I would be different now. I was going to have an abortion but the dad and I couldn't do it....I still remember thinking that nothing would ever be the same again but I wanted to keep the baby.
}

A lack of financial and emotional support impacted on their early experience of motherhood and Joanne believed that she was too young to make decisions for herself and her baby. The process of 'identity transformation' (Strauss 1962) that would take them from young women to mothers was particularly problematic for some of them because they had low self-esteem and they lacked the confidence to accept that they could be a 'good' mother.

Zoe: I knew that I was different to them... you know they were 'good' mothers and they would never be able to accept me into their group... so I made my mind up...I was different.

Zoe was comparing herself to other young mothers in her 'reference group' (Urry, 1973) but because she was lacking in confidence she felt unable to take up her new role. By drawing on the cultural narrative of the 'good' mother (Bamberg, 2004; Warnes \& Daiches, 2011), Zoe was limiting her opportunities to join the group. Lisa also found the transition into motherhood difficult as she felt unable to relate to the other young mothers in the group because she was from a middle-class family and felt very different to the other young women:

\footnotetext{
Lisa: The thing is I am different to them because my family is middle class and this sort of thing does not happen in families like mine. They were so shocked (her parents)...they wanted the best for me, you know...go to uni and get a good job.
}

The feeling of regret for Lisa was intense; she believed that she had disappointed her family and because she had found out that she was pregnant shortly after returning from her first holiday with a friend. For Lisa the change in status from a young carefree woman to a mother was difficult and one that she initially resisted: 
Lisa: I thought if I did get pregnant it would be fine. I would just keep it but when I got back [from holiday] and I found out that I was pregnant I was like... Oh God 'cos I had just been on holiday and it has opened my eyes to all the world and I realised that I wanted to travel.

This transition was also difficult for Lisa because her parents did not want her to continue with the pregnancy and she remembered the pressure that she felt at that time.

Lisa: It was bad at the start... they weren't too happy about who the father was, that and me being only being 18. They wanted me to have an abortion and for a while I considered it, I went to the doctors but I didn't go through with it.

Lisa's decision to carry on with the pregnancy represented a 'turning point' for her, a significant event in her life. It represented a move from one status to another (Strauss, 1962) and she understood that she had to accept her situation and start to plan for her future. Another 'turning point' for Lisa was her labour and the first few days after she became a mother:

Lisa: The whole thing [having the baby] was different really... different than what I expected. I thought I would be able to handle labour but I remember shouting... I need something else... and by the end I had completely lost control...but the worst bit was when I realised I was his mum.

Lisa's experience of giving birth was not unique, but rather than relief that it was all over, she described an overwhelming fear of so much responsibility and an all-encompassing feeling of loneliness. Although Lisa's family initially encouraged her to have an abortion, they later gave her a lot of assistance, with Lisa receiving more family support than any of the other mothers. Despite this, recalled that she felt 'alone', 'frightened' and overwhelmed with the way her life had changed. This impacted on Lisa's view of the 'self' (Mead, 1967) because she was no longer able to identify with her previous group of friends, however, she refused to 'fit-in' with the other young mothers at the Children's Centre. Lisa's experience of 'becoming' a mother demonstrated how she was resisting the 'status passage' (Glaser \& Strauss, 1971) from a young women to a mother because she was unable, or unwilling, to fully commit to either.

When you 'scratched the surface' it became apparent that the young women had faced a number of challenges that had made their transition into motherhood more difficult. These difficulties included relationship problems, addictions and depression. Joanne described how she had struggled to meet her child's needs at the same time as fighting her own addictions and she described how the task was more difficult because the child's father was in prison:

Joanne: I'd only just started going out with his dad. He was thirty... we got caught straight away... his dad's a bad seed, he's now in jail. It is a struggle and every day I think about if I will ever come through all this... 
This struggle that Joanne identifies was made more difficult because she felt that she was not fully informed about her contraception options and was therefore denied the opportunity to prevent her pregnancy:

Joanne: My doctor would not give me the pill because I was only fourteen at the time and I think that is wrong, people are still having sex under age so shouldn't the government help instead of refusing?

This comment from Joanne is in the form of an excuse where she attaches 'blame' for the pregnancy firmly with the doctor as he had refused to give her the pill. Despite feeling anger towards the doctor Joanne did not blame the father who was much older and he had a relationship with her when she was still a child. This attempt to 'scapegoat' the doctor, allowed Joanne to escape some responsibility for the pregnancy and for the addictions that had impacted on her ability to be a mother to her child.

Joanne: You see while I was trying to sort out all my problems I was missing out on all the great things about being a mother. I wish I could have just pressed the pause button and got myself sorted, and then I could have been a good mum. I just had so many things that got in the way and all the time that I was trying to sort things...he was getting bigger... and I missed it.

By participating in the group Joanne had the opportunity to see herself through the eyes of others (Mead, 1967) and she believed that because of how 'addicts' are represented in the media, the other mothers would not like her. Joanne felt 'stigmatised' within the group (Goffman, 1963) and despite the efforts that she was making to care for her child, they refused to accept her. The impact of this was easy to see and Joanne's self-esteem remained low and she was very 'vulnerable'.

From the stories that the mothers told it was clear that they were very aware of the cultural narratives surrounding motherhood and they experienced difficulty fitting in with what they thought was required. Zoe refused to accept that she could be a 'good' mother and she rejected the possibility that she could care for her children because of her financial situation. In contrast Lisa had more support and financial stability than the other mothers, but she still struggled to make the transition into motherhood because she regretted her pregnancy and she was aware that her parents were disappointed that she had become pregnant at such a young age. 
The transition for Joanne was complex as she felt stigmatised by the group due to her drug addiction and because she had become pregnant to a much older man who was now in prison. The impact of her addiction also meant that she had missed out on important memories from her child's development. There were no concerns about any of the mothers' abilities to care for their children but from their stories it was clear that they were experiencing a misalignment between their old status as a young women and their new status as a mother.

\section{“They were the worst days of my life”: Millie’s story}

One of the mothers in the study that had the most difficult journey was Millie because she had very little support from her family or friends and she was suffering from post-natal depression. When Millie told her story she wanted to make it clear that she still regretted getting pregnant at an early age because she felt that she had 'let people down' and ‘disappointed' her family. For Millie, being a teenage mother was 'problematic' and had led to her having a negative image of herself and a perception that other people would automatically view her negatively. These feelings were overwhelming for Millie and she talked about her anger at being 'let down' by her boyfriend because he had encouraged her to continue her pregnancy; however, within months they had separated, leaving Millie homeless and alone. It was difficult for Millie to share her story but when she did she described her experience as a 'living hell' and a nightmare that she could not wake up from:

\footnotetext{
Millie: To be honest I was that scared you won't believe how scared I was up until the minute I had him... right through my labour the one thing I was scared about was being able to look after him... being a parent, what do you do, how do you take a nappy off, how do you bath 'em, how do you feed 'em, how do you know when they want feeding and all the rest of it... and then because I had a C section I didn’t have him until the next day. So the next day it was like bump, he's there, do it... so I had to do it.
}

Millie had no previous experience to draw on and she was alone and lacking the necessary skills to care for her new-born. This lack of support impacted on Millie's emotional state during her pregnancy and she recalled this period of her life as very difficult; a time when she had considered suicide on a number of occasions and she was treated for depression. Although Millie had made progress the depression returned when she gave birth:

Millie: When I became a mum it all came flooding back and... I stopped trying because it was really hard. I remember one time that I went to pick him up [from the crèche] and I could have even killed myself rather than care for him...they got me to the psychiatrist and [I] got readmitted... then I got severe depression. 
The decision to keep her baby was fraught with difficulties and she still felt angry because she believed that she had been 'cheated' into keeping the baby, leaving her with a very different future to the one she had planned:

Millie: It would've been easier for him just to say I agree with you... I was totally against the idea [of keeping the baby] and he changed my mind and then for one reason or another he just got cold feet and went. I've been left with a 'little man' [her son]. I wouldn't change him now, don't get me wrong, I wouldn't change him for the world and I'm glad he's here, he's the best thing that's ever happened to me...but I know I am missing out.

Millie was reluctant to accept her new 'status' and she was having difficulty integrating with the young mothers in the support group. In many ways Millie was unable to construct a positive story about her own situation therefore she found it difficult to listen to the 'optimistic' stories that the others told (Miller, 2007). Despite this, Millie continued to come into the centre with support from the workers but she frequently left the group early:

Millie: When I talk to the other girls they are happy with the choice that they made to keep their baby but I just want to cry every morning when I think about my life. I had so much planned and I feel like I am just going through the motions of being his mom, I love him so much but I wish I was his sister...or his aunty...that way I could look after him and love him but someone else would be responsible for him...someone else would be his mom.

Millie's transition into motherhood had been traumatic for a number of reasons including post-natal depression, homelessness and a lack of support from her family and although she loved her baby, she resented being his mother. Despite this Millie recognised the need to accept her new 'status' but also understood that this would take time so she attempted to act out her role engaging in what Goffman (1959) described as impression management:

Millie: There [are] loads of new faces... so for me it is going to be like a fresh start and I am going to stick to everything and do my best...but it's hard. I don't feel like a mother and I don't want to feel like one - all the girls here love it and it's kind of expected of you so you have to act it out don't you?

In many ways Millie was resisting her transition into motherhood and she frequently stated that she felt overwhelmed with a sense of panic because of the realisation that she was responsible for her child. Millie described times when she would take her baby to the crèche and then consider walking away and never going back in an attempt to avoid the responsibility of motherhood. She spent the last few months of her pregnancy going from one house to another in search of a settee to sleep on and this continued for three months after she had her baby. For Millie the challenges that she faced were dominated by the lack of a secure place to live, however, in some ways her fears increased when she did find a home:

Millie: I think I was so busy thinking about where to sleep that night... I never had time to worry about being a mother. It was a bit like being in a dream, well a nightmare, but now I have too 
much time to think and when he is in bed I just sit here. At least when I was homeless I had something to focus on.

Despite securing housing, Millie was still experiencing feelings of loneliness and an overwhelming sadness and she felt that people would view her negatively for becoming a mother at an early age. Drawing on the normative construction of a teenage mother Millie was limiting the possibilities for her future because she was unable to see past the negative stereotypical view that was portrayed in the media. Millie's mental health issues made it very difficult for her to engage with the other mothers in the group meaning that she was unable to move forward and explore and validate her new status as a mother (Strauss, 1962). For these reasons the road to motherhood was difficult for Millie and she was reluctant to access the support that she needed because she was very reluctant to talk about the struggles that she had.

\section{"You have to let go of your regrets and move on": Turning the corner and} 'becoming' a mother.

Coming to terms with the emotional aspect of motherhood was a recurring theme in the mother's narratives and it was important for the young mothers to accept their status so that they can start to enjoy their role as a mother. This was difficult for many of the mothers and in Sarah's story she discussed how she had suffered from depression in her teenage years and although things had improved initially, she remembered that the birth of her child had resulted in her earlier depression returning:

Sarah: When I became a mum it all came flooding back and...then I got severe depression. The doctor said I want the truth, how are you actually feeling...I told him that I worry all the time about something being wrong with my baby. I worry all the time about her but that is not just because of depression, every mother worries...don't they?

Sarah recognised that she was experiencing high levels of anxiety but she was keen to normalise this by suggesting that worrying about one's children is something that every mother does. During her pregnancy, Sarah had concerns that if the depression returned the baby might be removed so she worked hard to present a positive image, especially when talking to workers. From Sarah's story it was clear that she was telling 'optimistic' stories in an attempt to present herself as a 'good' mother. Using these stories she was able to present her experiences in a positive light in order to avoid the 'stigma' that she felt was attached to both teenage motherhood and mental illness. 
Despite the positive 'performance' that Sarah was portraying, over time it was possible to build a relationship of trust and she was able to discuss the reality of her situation. Sarah had experienced a lot of change and the separation from her partner before the birth of her baby was a disappointment to her:

Sarah: I had already been a single mum and everyone looks down at you so now we were a couple we were trying and then we weren't... and then we split up and I found out I was pregnant, we had given up trying and it was...well a surprise. I thought it would not happen, especially when we were not trying.

Sarah wanted the opportunity to experience motherhood in a stable relationship perhaps in an attempt to construct a 'counter story' (Warnes \& Daiches, 2011) but her partner had ended their relationship and this left her to care for both children on her own. Chloe also attempted to justify having her baby at a young age with the suggestion that there were many advantages to having children at an early age:

\footnotetext{
Chloe: I had been with my partner for three years before we decided to have a child and it's good to be young as well you can do more things with them as you have got more energy. My brother and sister were fourteen and fifteen when they had kids, so I knew what I was letting myself in for by watching them... missing out on their lives and not being able to go out... I am not sure what I was expecting but most times it is good, but not always 'cos it can be hard.
}

Chloe was very aware of the 'cultural narratives' that surround teenage motherhood but she attempted to challenge this by noting that she had planned to have a baby because she was in a stable relationship. In addition Chloe draws on her experience of caring for young children within the family and suggests that it was inevitable that she would have a child at an early age. Chloe's 'identity transformation' was perhaps made easier because others in her family had become parents before the age of 16 and this had provided her with what Urry (1973) described as a 'reference group'.

The transition for Annie was different because she was living with her parents and she remembers that although she knew she was a mother, she continued to feel like a child. She had the 'best of both worlds' because she could move between her new role as a mother, while still feeling the security of being a child. Annie received a lot of support from her family initially but when she moved into her own flat she was forced to take full responsibility for her baby and for her is represented a 'turning point' (Strauss, 1962):

Annie: You see the thing is... it made me grow up man [having a baby]... and now I feel different to the people my age, and I think oh grow up... I don't get on with them... I only get on with people who have got kids. 
For Annie it was not until she started living independently that she really accepted that she was a mother who was responsible for herself and her child. Another positive aspect that was highlighted by some of the mothers was the suggestion that teenage motherhood provided the opportunity to give and receive what they described as 'unconditional' love:

Anne Marie: I guess it is unconditional love but not just from the children... for them as well. It's like I said, I would love him no matter what... I always love him no matter what. They are both little miracles in my eyes because I am not supposed to be able to have babies.

The special relationship that the young mothers had with their babies resulted in them reviewing their own experiences of being loved as a child and for some this was a difficult time. Experiencing the overwhelming love that they felt for their children reminded some of them that they had not always been given 'unconditional love'. Despite this, for some mothers, their relationships with their families remained strained and this had a negative impact because they were desperate for their families to view them positively:

Annie: It's all those memory things that might not mean anything to anybody else. I never had nothing, I think there's one photo of me as a baby...there's nothing until I was about five. I wanted to save all my memories of the early days...it makes you ask why they didn't keep pictures of me.

The realisation that their mothers had perhaps felt differently to the way they felt about their children was difficult to deal with and some of the young women would talk about their childhood with great sadness. The young mothers now understood what it meant to be really close to their children and for some this led to anger and frustration because they had not experienced what they described as 'unconditional love' from their parents.

\section{Discussion}

The young women in this study identified pregnancy as a period of change, a time when they had to get used to the idea that they were going to 'become' a mother and they recognised that this was the start of their journey. From the data it was possible to identify the factors that influenced the young mothers' transitions and these included: the degree of choice that they had; their opportunity to discuss their transition and the degree to which the change in status was desired. In addition, their transition into motherhood was influenced by the level of support that was available from family and friends, consequently, when this support was not available, it became problematic.

This paper has outlined how the experience of 'becoming' a mother took many forms along a continuum and the young mothers' needed to make sense of their transition from their life 
prior to the pregnancy to their new status as a mother. Drawing on the ideas of Strauss (1962) it has been suggested that their transition can be affected when there is a misalignment between their old status and their new one. This misalignment can be increased when the young women's reluctance to accept their new role in an attempt to avoid the negative construction of young mothers. This supports Thomson et al.'s (2008) supposition that young mothers experience a sense of the loss of their chance to be an independent woman as they had previously imagined. This misalignment meant that although they loved their babies, the young mothers needed the opportunity to explore their new role in order to validate their new status (Strauss, 1962) and for some this was a long process.

This paper has also highlighted the importance of listening to what young mothers say about their experiences in order to understand the complexity of their needs. Having the opportunity to share their stories offered the young mothers in this study the space to develop what Warnes \& Daiches (2011) described as 'counter stories' in their effort to resist the negative stereotypes that shape popular images of teenage mothering. By listening to the stories that the mother told, it was possible to capture the 'critical incidents' and 'turning points' on their individual road to 'becoming' and more importantly, this transition did not necessarily happen when they gave birth.

Although on the surface the young women appeared to have accepted their new role as mothers, the journeys that they had taken included both high and low points. The joy that children had brought to their lives was evident but this was also tainted with sadness and grief for what might have been. When you 'scratched the surface' there were often tears and regrets alongside the pride and happiness. To some extent the young women felt uplifted since they had become mothers and viewed themselves in a more positive light and this had improved their self-esteem. This positive view was often linked to feeling that this was a 'second chance', an opportunity to do things differently and the chance to be 'proud'. Without exception the young women had high aspirations for their children and wanted to take steps towards providing what they felt their children needed.

By having an awareness of the cultural narratives, myths and stereotypes that surround teenage motherhood it is possible for practitioners to support the young mothers to develop positive mothering practices within an environment where they feel able to seek support when needed. By spending time with the young mothers it was possible to understand the reality of early motherhood and get beyond the 'optimistic' stories that they told in their 
'front-regions' (Goffman, 1959). The young women actively engaged in the 'telling' and 'retelling' of these 'optimistic' stories in their efforts to present themselves in a positive light, however, overtime it was also possible to identify how the stories that they told changed depending on the audience. It is also important to note that the stories the young women 'presented' were only one version of reality and will have been informed and shaped by the cultural narratives that surround teenage motherhood.

The findings from this study have implications for the professionals who are charged with supporting young vulnerable mothers and ensuring the safety of their children. Listening to, and understanding, the stories of the young mothers was not an easy task especially when there were child protection concerns or the mother's experience of motherhood was less positive than she expected. In both of these instances the findings from this study suggest that young mothers will engage in what Goffman (1959) described as the 'dramaturgical metaphor' in their effort to present workers with a positive reflection of their experience. This is an important point when planning support for young mothers because their support needs can change over time linked to important life events such as living independently or separating from a partner.

The findings suggest that over time it is possible to engage young mothers in more productive discussions where they are able to share the reality of their situation and identify the support that they need. Although, as previously discussed, the road to 'becoming' a mother was difficult for some, there were also a lot of positive points in their stories and many of them suggested that the love that they felt for their children helped them to overcome a range of difficulties. Many of the mothers had the opportunity to stop and 'take stock' (Strauss, 1962) and they realised that, despite the challenges they faced, they had survived and were feeling stronger and able to plan for their future. Despite the difficulties that the young women had experienced in the early days, most of them were starting to embody their new identity as a mother with a belief that their future was brighter because having a child represented a point at which they could look back and be proud. 


\section{$\underline{\text { References }}$}

Allen, K. \& Taylor, Y. (2012) Placing parenting, locating unrest: Failed femininities, troubled mothers and riotous subjects. Studies in the Maternal, 4(2), 1-25.

Allen, K. \& Osgood J. (2009) Young women negotiating maternal subjectivities: The significance of social class. Studies in the Maternal, 1(2), 1-17.

Arai, L. (2009) Teenage pregnancy: The making and unmaking of a problem. Policy Press: Bristol.

Bamberg, M. (2004) Considering counter-narratives. In Bamberg, M. \& Andrews, M. (eds.) Considering counter-narratives: Narrating, resisting, making sense. Amsterdam: John Benjamins Publishing, 351-71.

Blaufuss, K. (2007) De-linking text from fieldwork: Exploring power imbalances in the narrative. Narrative Inquiry, 17(1), 13-26.

Bleakley, A. (2005) Stories as data, data as stories: making sense of narrative inquiry in clinical education. Medical Education, 39(5), 534-40.

Burk, C. (2005) Comparing qualitative research methodologies for systemic research: The use of grounded theory, discourse analysis and narrative analysis. Journal of Family Therapy, 27(3), 237-62.

Crang, M. \& Cook, I. (2007) Doing ethnographies. London: Sage Publications Ltd.

Creswell, J. W. (2007) Qualitative inquiry and research design: Choosing among five approaches. $2^{\text {nd }}$ ed. London: Sage Publications Ltd.

Feldman, M. S., Sköldberg, K., Brown, R. N. \& Homer, D. (2004) Making sense of stories: A rhetorical approach to narrative analysis. Journal of Public Administration Research \& Theory, 14(2), 147-70.

Flick, U. (2009) An introduction to qualitative research. 4th ed. Sage Publications Ltd: London.

Glaser, B. G. \& Strauss, A. (1971) Status passage: A formal theory. London: Routledge \& Kegan Paul.

Goffman, E. (1959) The presentation of self in everyday life. St Ives: Clays Ltd.

Goffman, E. (1963) Stigma notes on management of a spoilt identity. St Ives: Clays Ltd.

Gomm, R. (2008) Social research methodology: A critical introduction. $2^{\text {nd }}$ ed. Basingstoke: Palgrave Macmillan. 
Gregson, J. (2009) The culture of teenage mothers. Albany: State University of New York Press.

Macvarish, J. (2010) Understanding the significance of the teenage mother in contemporary parenting culture. Sociological Research Online [online]. 15, [Accessed February 2012].

Available at: <http://www.socresonline.org.uk/15/4/3.html>.

Mead, G. (1967) Mind, self and society: From the standpoint of a social behaviourist. In Works of George Herbert Mead, Vol. 1. Morris CW. (ed.). London: University of Chicago Press.

Miller, T. (2007) Is this what motherhood is all about?: Weaving experiences and discourses through transitions to first-time motherhood. Gender \& Society, 21(3), 337-58.

Oakley, A. (1979) Becoming a mother. Oxford: Martin Robertson.

Oakley, A. (2005) The Ann Oakley reader: gender, women and social science. Policy Press: Bristol.

Read. D, Crockett, J. \& Mason, R. (2012) “It was a horrible shock” The experience of motherhood and womens' family size preferences. Women's studies international forum, 35(1), 12-21.

Rowlingson, K. \& McKay, S. (2005) Lone motherhood and socio-economic disadvantage: insights from quantitative and qualitative evidence. The Editorial Board of the Sociological Review, 51(1), 30-49.

Rutman, D., Strega, S., Callahan, M. \& Dominelli, L. (2002) 'Undeserving’ mother? Practitioners' experiences working with young mothers in/from care. Child \& Family Social Work, 7(3), 149-59.

Shibutani, T. (1955) Reference groups in perspectives. The American Journal of Sociology, 60(6), 562-9.

Shibutani, T. (1962) Reference groups and social control. In Rose, A (ed.) Human behaviour and social processes: An interactionist approach. London: Routledge \& Kegan Paul, 128-47.

Strauss, A. (1962) Transformation of identity. In Rose, A. (ed.) Human behaviour and social processes: An interactionist approach. London: Routledge \& Kegan Paul, 63-85.

Taylor, S. (2003) A place for the future? Residence and continuity in women's narratives of their lives. Narrative Inquiry, 13(1), 193-215.

Thomson, R., Kehily, M. J., Hadfield, L. \& Sharpe, S. (2008) The making of modern motherhood: memories, representations, practices. Full Research Report - ESRC End of award report. RES-148-25-0057. Swindon: ESRC.

Urry, J. (1973) Reference groups and the theory of revolution. London: Routledge. 
Walkerdine, V., Lucey, H. \& Melody, J. (2001) Growing up girl: Psychosocial exploration of gender and class. London: Palgrave.

Warnes, J. \& Daiches, A. (2011) 'Rebuilding after the storm': Stories of young motherhood. Narrative Inquiry, 21(1), 109-29.

Wilson, H. \& Huntington, A. (2005) Deviant (m)others: The construction of teenage motherhood in contemporary discourse. Journal of Social Policy, 35(1), 59-76. 